\title{
DEFB103A wt Allele
}

National Cancer Institute

\section{Source}

National Cancer Institute. DEFB103A wt Allele. NCI Thesaurus. Code C91754.

Human DEFB103A wild-type allele is located in the vicinity of 8p23 and is approximately 1 $\mathrm{kb}$ in length. This allele, which encodes beta-defensin 103 protein, plays a role in the mediation of host defenses. 